\title{
6. PASS-THROUGH CORE MEASUREMENTS OF MAGNETIC SUSCEPTIBILITY AND NATURAL GAMMA RAY, NEW JERSEY COASTAL PLAIN ${ }^{1}$
}

\author{
John M. Metzger, ${ }^{2,4}$ Steven C. Remer, ${ }^{2}$ Kenneth G. Miller, ${ }^{2,3}$ Dennis V. Kent, ${ }^{3}$ Mickey C. Van Fossen,,${ }^{2,3}$ \\ James V. Browning, ${ }^{2}$ and Dave S. Goldberg ${ }^{3}$
}

\begin{abstract}
We measured magnetic susceptibility (MS) and core gamma radiation (CGR) on $3162 \mathrm{ft}$ (963.9 m) of core recovered by the New Jersey Coastal Plain Drilling Project (Ocean Drilling Program Leg 150X) at Island Beach, Atlantic City, and Cape May, New Jersey. Integration of core lithology, core/log (MS and CGR), and downhole gamma-ray (DGR) log studies have (1) documented the core/log expression of previously determined unconformities; (2) shown that MS is a proxy for glauconite percent in the New Jersey Coastal Plain; (3) illustrated a major change in sedimentation from shelfal glauconite evidenced by very high MS values to deltaic deposition with low MS values in the earliest Miocene (ca. $22 \mathrm{Ma}$ ); (4) shown that comparison of MS and CGR with DGR can be used to resolve discrepancies in depth between downhole logs and cores; and (5) shown that the CGR detects some zones noted in the lithology (e.g., phosphate rich zones) that are not resolved in the DGR.
\end{abstract}

\section{INTRODUCTION}

The New Jersey Coastal Plain Drilling Project (Ocean Drilling Program [ODP] Leg 150X; Miller et al., 1994a, 1994b; Miller, et al., 1996) continuously cored and logged boreholes at Island Beach (1223 $\mathrm{ft}, 372.9 \mathrm{~m}$ total depth (TD) in Maastrichtian), Atlantic City (1450 ft, $442.1 \mathrm{~m}$ TD in middle Eocene), and Cape May (1500 ft, $457.3 \mathrm{~m}$ TD in upper Eocene; Fig. 1). Previous studies have identified sequences in the cores as generally shallowing upward successions and dated them with integrated magnetostratigraphy, biostratigraphy, and Sr-isotopic stratigraphy (Miller, et al., 1996; Miller et al., 1994a, 1994b, and studies in this volume). Although recovery was excellent at all three sites (>80\% mean), coring gaps limit stratigraphic resolution in critical intervals. Downhole gamma-ray (DGR) and other downhole logs can be used to evaluate sequences, particularly in intervals of poor recovery. Pass-through logging techniques can be applied to the recovered cores, enhancing information available from conventional downhole logs alone. In addition, integration of core logs and downhole logs allows the calibration of these two data sets, resulting in proper depth placement of the core relative to the DGR and other downhole logs.

Although pass-through measurements of some core properties, such as gamma-ray attenuation and porosity evaluator (GRAPE), have been routine on Deep Sea Drilling Project (DSDP) and ODP cruises, modern multisensor tracks have only recently become available. Core gamma radiation (CGR) was added as a standard multisensor track measurement on the JOIDES Resolution as recently as Leg 150 (Hoppie et al., 1994). In the Paleomagnetics Laboratory at Lamont-Doherty Earth Observatory (LDEO), a multisensor track was designed and developed for the last hole of the Newark Basin coring project (e.g., Kent et al., 1995) and built by ASC Inc. in 1993. The track allows (stationary) measurements of contiguous intervals of core in pass-through mode and is currently configured to measure magnetic susceptibility (MS) and CGR at predetermined intervals. Although the technique is best applied to freshly obtained cores (i.e.,

${ }^{1}$ Miller, K.G., and Snyder, S.W. (Eds.), 1997. Proc. ODP, Sci. Results, 150X: College Station, TX (Ocean Drilling Program). U.S.A.

${ }^{2}$ Department of Geological Sciences, Rutgers University, Piscataway, NJ 08855,

${ }^{3}$ Lamont Doherty Earth Observatory of Columbia University, Palisades, NY 10964, U.S.A.

${ }^{4}$ Correspondence author: jmm@essc.psu.edu before sampling and shrinkage), the track was not available when the Island Beach and Atlantic City cores were obtained in March to August, 1993. Cores obtained by Leg $150 \mathrm{X}$ were measured using the LDEO multisensor track from June to November 1995. This contribution presents CGR and MS data for the Island Beach, Atlantic City, and Cape May boreholes.

\section{METHODS \\ Data Collection}

Core/log data were measured on the intervals 0-1223 $\mathrm{ft}(0-373 \mathrm{~m}$; $1060 \mathrm{ft}[323.1 \mathrm{~m}]$ recovered) from Island Beach, 0-1452 ft (0-443 m; $977 \mathrm{ft}[297.8 \mathrm{~m}]$ recovered) from Atlantic City, and 0-1500 ft (0-457 $\mathrm{m} ; 1125 \mathrm{ft}[343.0 \mathrm{~m}]$ recovered) from Cape May using the LDEO Autotrak system. Preliminary specifications for the setup of the project came from guidelines established for Leg 150 CGR studies (Hoppie, et al., 1994). The cores were passed through both the CGR counter and the MS meter with measurements taken at stationary 3-in (7.62 $\mathrm{cm}$ ) intervals. The MS meter used in this study was the Bartington Magnetic Susceptibility Meter Model MS2, similar to the instrument used on board the JOIDES Resolution, with a 100-mm-diameter sensor. The CGR counter used a Canberra multichannel system with $\mathrm{NaI}$ detector operated in total natural gamma mode.The sensor is a multichannel passive gamma-ray counter, with each channel recording the number of gamma-rays detected (e.g., from the different isotopes of $\mathrm{U}$, Th, and $\mathrm{K}$ present in the sample) per second. The multichannel counts at each depth interval were then combined to get a total counts per second. Magnetic susceptibility and natural gamma radiation is influenced by the volume and geometry of the core placed in the sensor. A reference sample at a known CGR signal of 12 counts s ${ }^{-1}$ and MS signal of 63.3 raw cgs, showed that the nominal stratigraphic resolution of the detectors was about 3 in.

For this survey study, CGR measurements used a count time of 10 $\mathrm{s}$ for each 3-in $(10.3 \mathrm{~cm})$ section; MS measurements were made simultaneously within this time interval on an offset section of core. Hoppie et al. (1994) noted that $30 \mathrm{~s}$ apparently provided the best compromise between sampling statistics and sampling time for CGR data (i.e. $11.2 \%$ standard error at $10 \mathrm{~s}$ and a $5.6 \%$ standard error at $30 \mathrm{~s}$ for Leg 150). Our comparison of CGR repeat data shows that although $10 \mathrm{~s}$ apparently captures much of the 30 -s signal, significant loss or aliasing is possible in the 10 -s measurements. To increase the statis- 


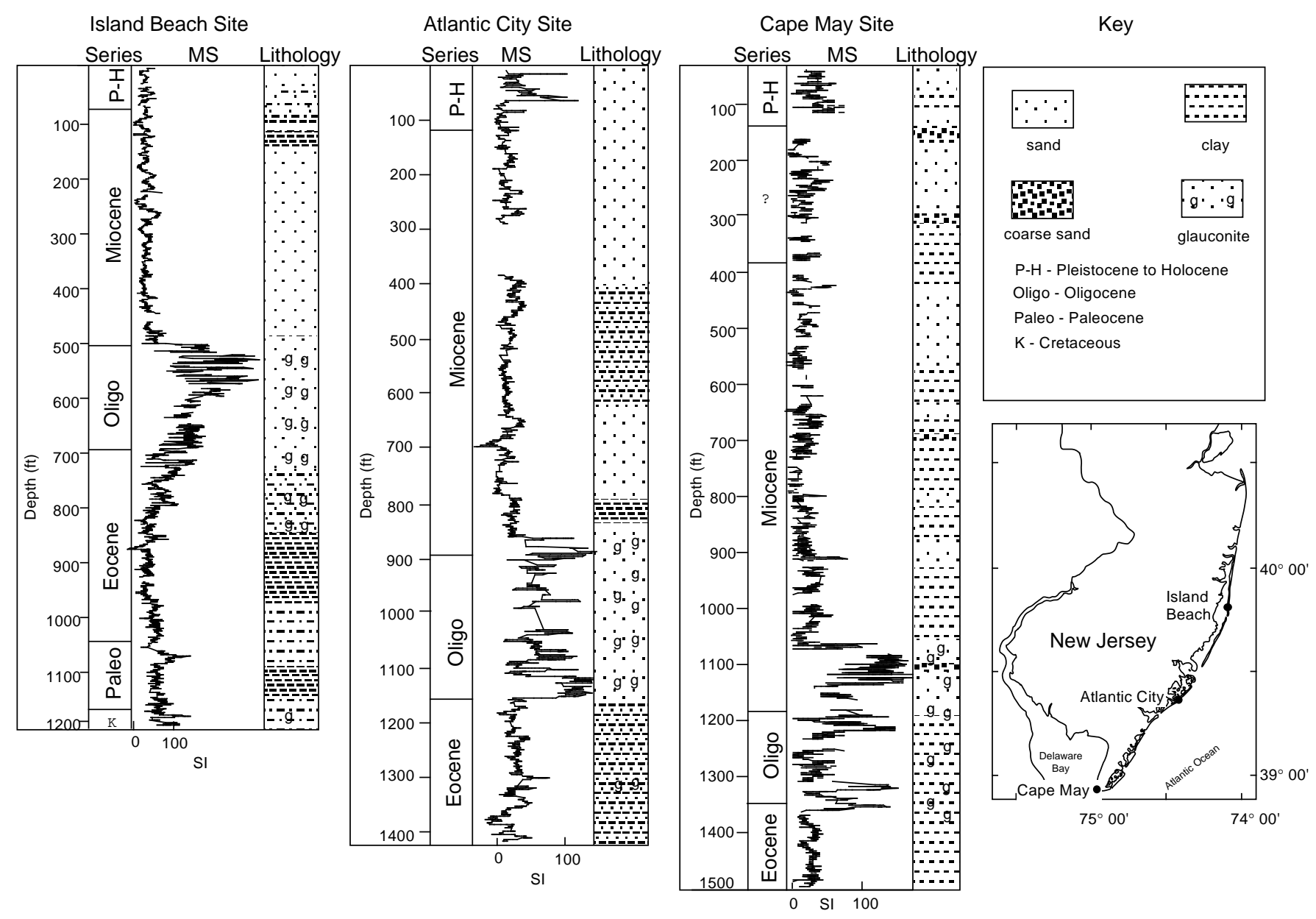

Figure 1. Magnetic susceptibility (MS) data for Leg 150X boreholes showing generalized lithostratigraphy derived from site reports (Miller et al., 1994a, 1994b; Miller, et al., 1996; SI $\left.\times 10^{-6}\right)$.

tical confidence of the CGR data, a 30-s sampling time is recommended in future work.

Although the CGR multichannel counter collected spectral gamma-ray data that would potentially allow the K, U, and Th components to be resolved, our routine sampling times were not sufficiently long to obtain accurate counting statistics for spectral deconvolution. The total counts obtained reflect the contribution of $\mathrm{K}, \mathrm{Th}$, and $\mathrm{U}$. Hesselbo (1996) provides a useful review of the contribution of each component to spectral DGR logs obtained on New Jersey slope Leg 150.

All downhole logs were obtained with slimline tools by BPB Instruments and are described by Miller et al. (1994a, 1994) and Miller, et al. (1996). At Island Beach, the hole was cased with polyvinyl chloride (PVC) pipe to $457 \mathrm{ft}(139 \mathrm{~m})$, and the following measurements were obtained on each formation from surface to $1221 \mathrm{ft}$ (372.3 m): (1) DGR and focused electric (resistivity); (2) multichannel sonic; (3) dual-spaced neutron; (4) gamma density caliper; (5) dipmeter; and (6) temperature. The gamma-ray logs at Atlantic City and Cape May were obtained through the drill pipe to total depth, which suppresses the value of the gamma-ray signal at these sites.

The DGR logs at these sites have a sampling interval of $0.01 \mathrm{ft}$ $(0.12$ in, $0.25 \mathrm{~cm})$, but were decimated to match the intrinsic 12 - to $15-\mathrm{cm}$ resolution of the DGR sensor (Goldberg et al., 1994). The CGR measurements therefore have somewhat higher stratigraphic resolution than the DGR, but the DGR tool typically measures higher count rates than the CGR because of the larger volume of sediment investigated.

\section{Data Processing}

The raw MS data, like the raw CGR data, were corrected for drift and background with "baseline readings" taken at 10-ft (3-m) intervals. The Leg $150 \mathrm{X}$ cores are whole cores with diameters of 1.875 in and 2.5 in (see Miller et al. [1994a, 1994b] and Miller, et al. [1996] for specific core diameters). The raw MS and CGR data were converted to volume specific data using the correction factor $(\mathrm{F}=0.87$ for 2.5 -in $[6.35 \mathrm{~cm}]$ core diameter; $\mathrm{F}=0.48$ for 1.875 -in $[5 \mathrm{~cm}]$ core diameter) for the 100 -mm-diameter sensor provided by the manufacturer. MS was measured in cgs units (gain = 1.0) and later converted to SI units using the equation:

$$
\mathrm{KSI}=([\mathrm{Kcgs}] /[0.87 \text { or } 0.48]) \times 4 \pi
$$

For both the CGR and MS, we smoothed the data as indicated below for each site. Primary sources of high frequency "noise" are coring voids, gaps from where samples were taken, and variations due to counting statistics for the CGR data. We tried to account for voids and gaps by eliminating the associated measurements close to background values in both MS and CGR. After experimenting with different running mean filters, a 9-in $(22.9 \mathrm{~cm})$ filter seemed to yield the clearest MS record with the least signal degradation and fewest artifacts and was thus used on the MS data. Similar studies (e.g., Hoppie et al., 1994) show that a 30-in $(76 \mathrm{~cm})$ filter was most suitable for CGR data, and thus it was used on the CGR data. Finally, intervals 
with less than $50 \%$ recovery were removed from the final data to avoid severe artifacts associated with frequent or large voids.

\section{RESULTS}

\section{MS and CGR vs. Lithology}

Comparisons of pass-through MS and CGR log data to the lithologies (Figs. 1-9) observed in the core revealed the following trends.

1. Percent glauconite is the factor that most influences MS signal strength. The first-order trend observed at all three sites is an interval of very high MS values corresponding approximately to the Oligocene to lowermost Miocene section (Fig. 1). At Island Beach, a major drop in the MS values occurs at the disconformable contact between the Oligocene and Miocene (hiatus between 24.3 and 21.6 Ma; Miller et al., 1994a). At Atlantic City, this change occurs in the lowermost Miocene at the contact between the Kw0 and Kw1 a sequences (between 22.2 and 21.4 Ma). At Cape May, the change also occurs at the $\mathrm{Kw} 0 / \mathrm{Kw} 1$ a contact (between 22.5 and $20.7 \mathrm{Ma}$ ), although elevated values continue into the base of the Kw1a sequence. This change represents a dramatic shift from shelf- to deltaicdominated sedimentation that occurred at ca. 22.2-21.4 Ma (see Miller et al., this volume for discussion of Miocene age control on the Leg 150X boreholes). The influence of glauconite is illustrated by matching a MS signal and the sieved weight percent of glauconite in the interval of $450-800 \mathrm{ft}$ (137.2-243.9 m) at Island Beach (Fig. 2). Future studies on the rock magnetic properties will need to be done to quantify this relationship.

2. Glauconite displays a CGR signal similar to, but slightly greater than, clay. Dramatic increases in MS values occur at all three sites when glauconite first appears downsection; these increases are not as apparent in the pass-through CGR logs because the latter also reflect the relative influence of clays (Figs. $5,7,9)$.

3. In the absence of glauconite, clays display high MS values relative to quartz sands. For example, clay-rich intervals at $\sim 450$ $\mathrm{ft}(137.2 \mathrm{~m})$ and $255-279 \mathrm{ft}(77.7-85.1 \mathrm{~m})$ at Island Beach show high MS values (Fig. 4).

4. Sands display the lowest MS signals relative to clay and glauconite. The best example of this is at Island Beach in the interval between 750 and $800 \mathrm{ft}$ (229 and $244 \mathrm{~m}$; Fig. 5).

\section{CGR vs. DGR Comparison}

Comparison of the CGR with the DGR at Atlantic City and Cape May shows that CGR often has much higher amplitude signals and displays peaks and troughs not present, or slightly offset from peaks in the downhole logs. We attribute this to four effects.

1. Most Leg 150X downhole logs (gamma and neutron) were obtained by logging the holes through drill rods. Downhole logging through a drilling rod causes attenuation of the signals relative to logs obtained in open hole or directly on the cores. The pass-through logging technique on core provides stronger signals than the DGR logs through the pipe. Pratson et al. (1992) show excellent examples of DGR logs through pipe that are correlated with carbonate, sandstone, and claystone lithologies recovered on the Exmouth Plateau (ODP Leg 122). An example of CGR showing peaks attenuated by logging through pipe is provided by figure 9 in Hoppie et al. (1994), similar to examples from Leg $150 \mathrm{X}$ sites that were logged through pipe (e.g., Atlantic City and Cape May).

2. The stationary and discrete sampling interval of the passthrough technique can image some horizons better than down-

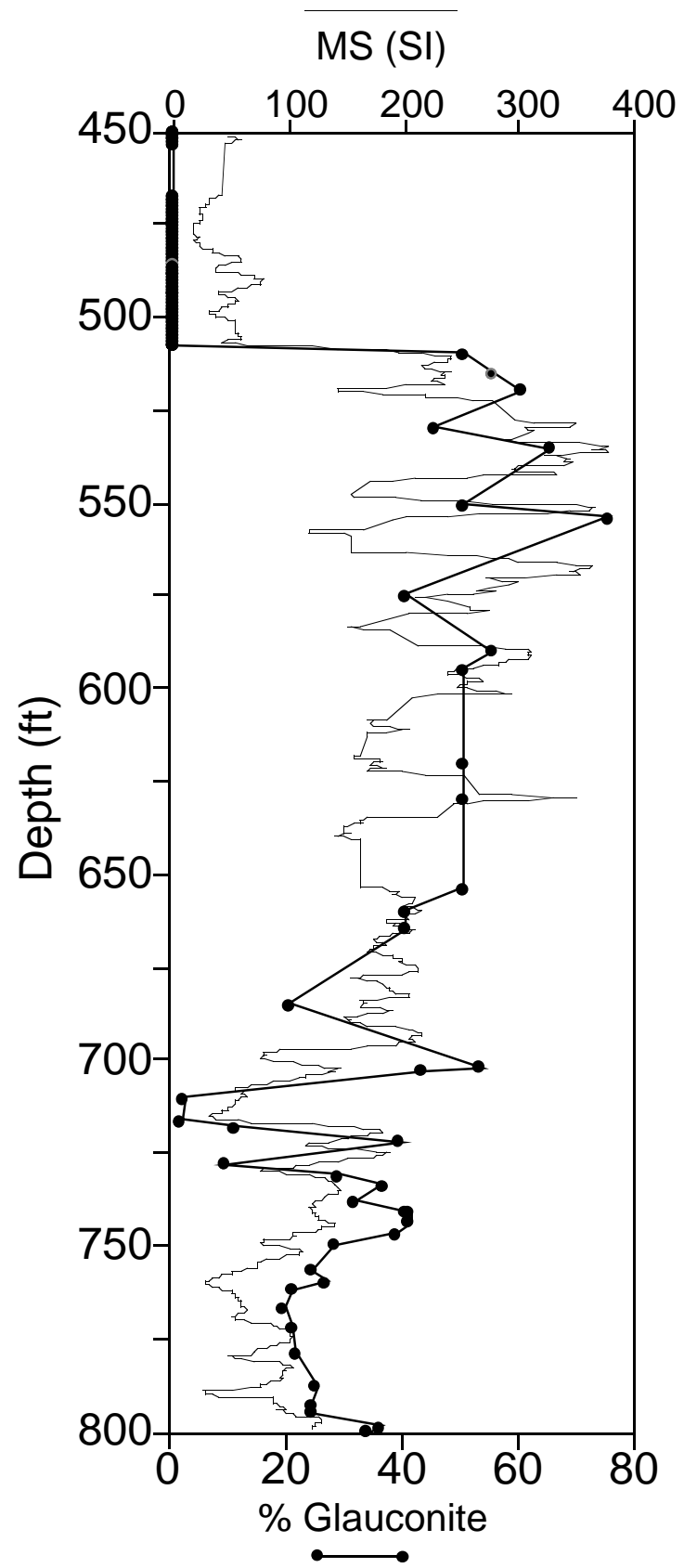

Figure 2. Relationship between glauconite percent and MS signal strength, Island Beach, $450-800 \mathrm{ft}\left(\mathrm{SI} \times 10^{-6}\right)$.

hole logs (Hoppie et al., 1994). This is shown at 421, 510, 680, and $854 \mathrm{ft}(128.4,155.5,207.3$, and $260.4 \mathrm{~m}$, respectively; Figs. 8,9) at Cape May where indurated zones containing small pebble-sized phosphatic nodules are resolved as peaks in the CGR and not in the DGR. This is partly because of the fact that in these intervals the DGR was run through the drill pipe, causing attenuation of the signal. It may also result from the fact that downhole logs image considerable volumes of sediment, thus averaging out these discrete intervals. These horizons may also be thinner than the minimum vertical resolution of the DGR tool.

3. The precise depths of cores are only known within a few feet; offsets between DGR and CGR/MS/lithology may thus be artifacts, and comparisons of CGR and DGR can be used to cor- 


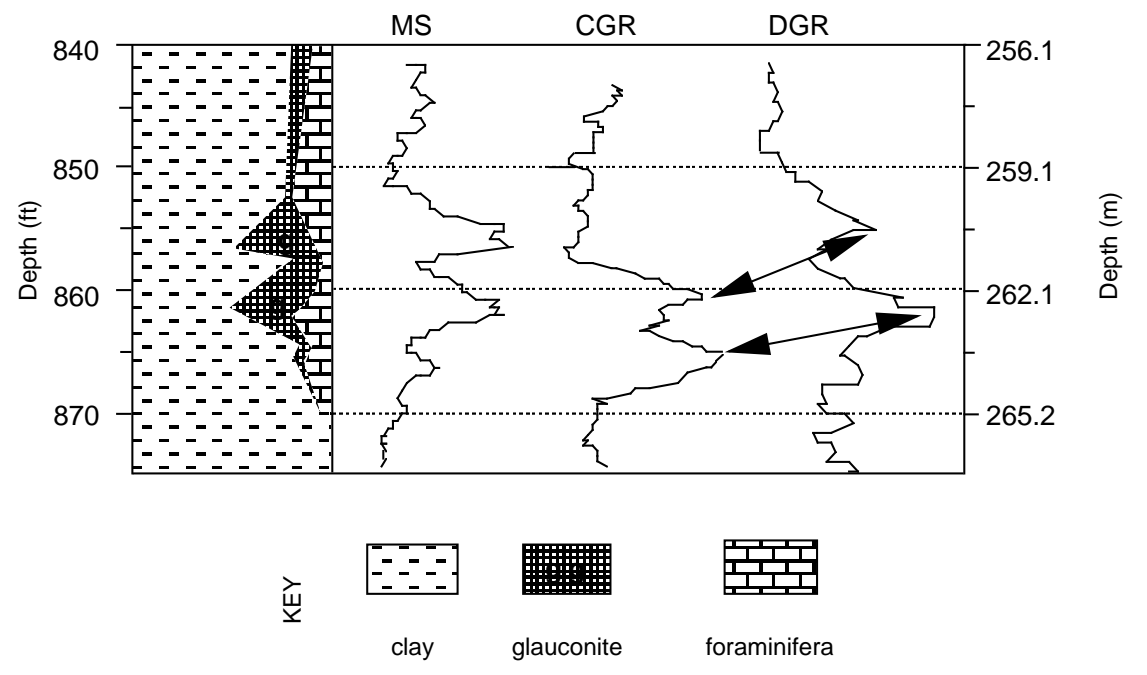

Figure 3. Details of the lower/middle Eocene boundary at Island Beach showing the depth placement differences between the DGR and CGR. rect these errors. The differences in detail in the interval from 846 to $876 \mathrm{ft}(258-267 \mathrm{~m})$ illustrate offsets between DGR and CGR/MS/lithologic peaks (Fig. 3). The MS peaks at 857 and $862 \mathrm{ft}$ (261.3 and $262.8 \mathrm{~m}$ ) correspond precisely with glauconite peaks noted in the core and are causally linked. Whereas the DGR shows peaks at about these depths, the CGR shows large peaks centered at $860 \mathrm{ft}(262 \mathrm{~m})$ and $868 \mathrm{ft}(264.6 \mathrm{~m})$, which are intervals of peak clay content. Intervals such as these having poor correlation between CGR and DGR logs are likely caused by depth uncertainty of the core samples. In addition, poor counts statistics can exacerbate CGR/DGR correlation problems, particularly in intervals of low gamma-ray emissions (e.g. sands). In this specific case, we minimized counting problems by choosing an interval of high gamma values and by counting at $30 \mathrm{~s}$. We conclude that the interval shown in Fig. 3 documents a clear misregistry in depth between core and DGR data. Other similar offsets occur in Atlantic City at $240 \mathrm{ft}(73.2 \mathrm{~m})$ and in Cape May between 275 and $280 \mathrm{ft}(83.8-85.4 \mathrm{~m})$ and 1060 and $1062 \mathrm{ft}(323.2$ and $323.8 \mathrm{~m})$.

4. The CGR resolves several fine-scale cycles that may be interpreted as parasequences (i.e., successions bounded by flooding surfaces). For example, in the Island Beach Miocene Kirkwood Formation $(78-508 \mathrm{ft}$ [23.8-154.9 m]), the passthrough technique allows for better resolution of several cycles shown by decreasing CGR values upsection. These are interpreted as stacked parasequences within the overall shallowing upward Kw1a, Kw1b, and Kw2a sequences. Although most of these are reflected in the DGR (Fig. 4), others are not, in part, because logs were obtained through the pipe.

\section{DISCUSSION}

The data presented here from the Island Beach, Atlantic City, and Cape May boreholes demonstrate the potential of core/log data for complementing conventional downhole logs and lithologic studies of cores. Such syntheses may enhance stratigraphic interpretations, especially the delineation of stratal surfaces (unconformities/sequence boundaries, flooding surfaces and transgressive/ravinement surfaces), facies changes within sequences (i.e., Systems Tracts of Posamentier et al., 1988), and proper depth and thicknesses of sequences. We caution that such studies are in their infancy and that the observations made in one setting do not necessarily apply in others. For example, Leg 150 drilling on the New Jersey slope showed that highMS values are associated with intervals of coarser sediments because of detrital input during glacial intervals (Mountain, Miller, Blum et al., 1994); on shore we show that high-MS values correspond with glauconite sands. We are still in an inductive mode of interpreting changes in core log data as proxies for lithologic or paleoenvironmental changes. Despite these limitations, our results have been encouraging. We find that the CGR logs may delineate thin phosphaterich horizons that are not observed in the through-pipe DGR logs. core. Both the CGR and MS logs could be used to delineate stratigraphic successions and be readily interpreted in terms of sequence stratigraphy.

\section{ACKNOWLEDGEMENTS}

We thank G. Mountain for discussions, and S. Hesselbo, B. Hoppie, and S. Snyder for reviews. This study was part of Senior Honors Theses at Rutgers University (Metzger and Remer). Supported by NSF Grants EAR92-18210 and 94-17108. This is LDEO contribution 5668.

\section{REFERENCES}

Goldberg, D.J., Reynolds, D.J., Williams, C.F., Witte, W.K., Olsen, P.E., and Kent, D.V., 1994. Well logging results from the Newark Rift Basin Coring Project. Sci. Drilling, 4:267-279.

Hesselbo, S.P., 1996. Spectral gamma-ray logs in relation to clay mineralogy and sequence stratigraphy, Cenozoic of the Atlantic margin, offshore New Jersey. In Mountain, G.S., Miller, K.G., Blum, P., Poag, C.W., and Twitchell, D.C. (Eds.), Proc. ODP, Sci. Results, 150: College Station, TX (Ocean Drilling Program), 411-422.

Hoppie, B.W., Blum, P., and Shipboard Scientific Party, 1994. Natural gamma-ray measurements on ODP cores: introduction to procedures with examples from Leg 150. In Mountain, G.S., Miller, K.G., and Blum, P., et al., Proc. ODP, Init. Repts., 150: College Station, TX (Ocean Drilling Program), 51-59.

Kent, D.V, Olsen, P.E., Witte, W.K., 1995. Late Triassic-earliest Jurassic geomagnetic polarity sequence and paleolatitudes from drill cores in the Neward rift basin, eastern North America. J. Geophys. Res., 100:14,96514,998

Miller, K.G., et al., 1996. Proc. ODP, Init. Repts., 150X (Suppl.): College Station, TX (Ocean Drilling Program).

Miller, K.G., Browning, J.V., Liu, C., Sugarman, P., Kent, D.V., Van Fossen, M., Queen D., Goss, M., Gwynn, D., Mullikin, L., Feigenson, M.D., Aubry, M.-P., and Burckle, L.D., 1994a. Atlantic City site report. In Miller K.G., et al., Proc. ODP, Init. Repts., 150X: College Station, TX (Ocean Drilling Program), 35-55.

Miller, K.G., Sugarman, P., Van Fossen, M., Liu, C., Browning, J.V., Queen D., Aubry, M.-P., Burckle, L.D., Goss, M., and Bukry, D., 1994b. Island 
Beach site report. In Miller K.G., et al., Proc. ODP, Init. Repts., 150X: College Station, TX (Ocean Drilling Program), 5-33.

Mountain, G.S., Miller, K.G., Blum, P., et al., 1994. Proc. ODP, Init. Repts., 150: College Station, TX (Ocean Drilling Program).

Posamentier, H.W., Jervey, M.T., and Vail, P.R., 1988. Eustatic controls on clastic deposition, I. Conceptual framework. In Wilgus, C.K., Hastings, B.S., Ross, C.A., Posamentier, H.W., van Wagoner, J., and Kendall, C.G.St.C. (Eds.), Sea-Level Changes: An Integrated Approach. Spec. Publ.-Soc. Econ. Paleontol. Mineral., 42:109-124.
Pratson, E.L., Golovchenko, X., and Broglia, C., 1992. Data report: geochemical results from wireline logs at Sites 761, 762, and 764. In von Rad, U., Haq, B.U., et al., Proc. ODP, Sci. Results, 122: College Station, TX (Ocean Drilling Program), 861-879.

Date of initial receipt: 26 February 1996

Date of acceptance: 14 August 1996

Ms 150XSR-305

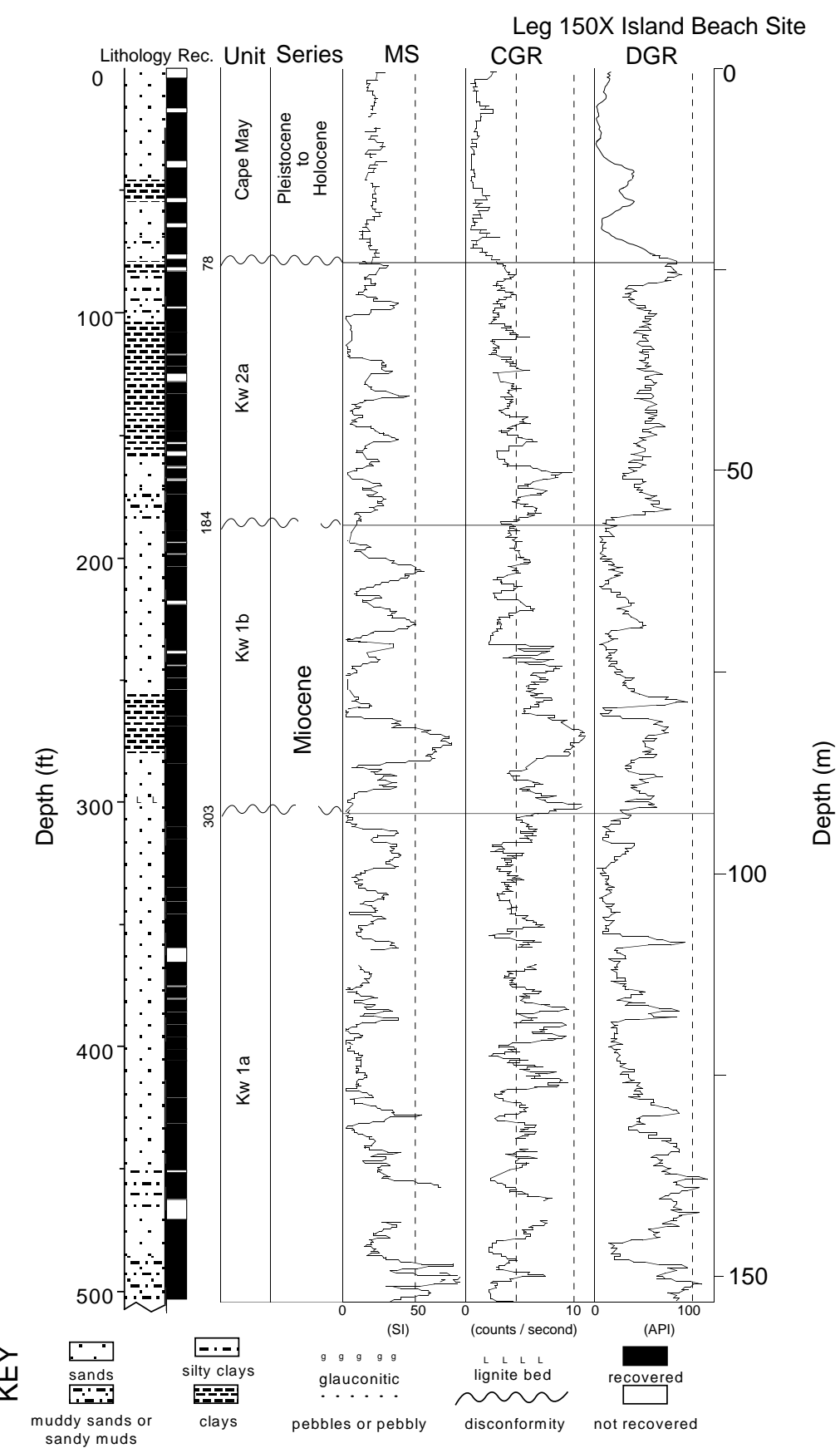

Figure 4. Miocene lithostratigraphy, recovery, sequences, ages, MS, CGR, and DGR log, Island Beach (0-500 ft). Lithology modified after Miller et al., (1994b). Open intervals are sections with no recovery $\left(\mathrm{SI} \times 10^{-6}\right)$. 
Leg 150X Island Beach Site

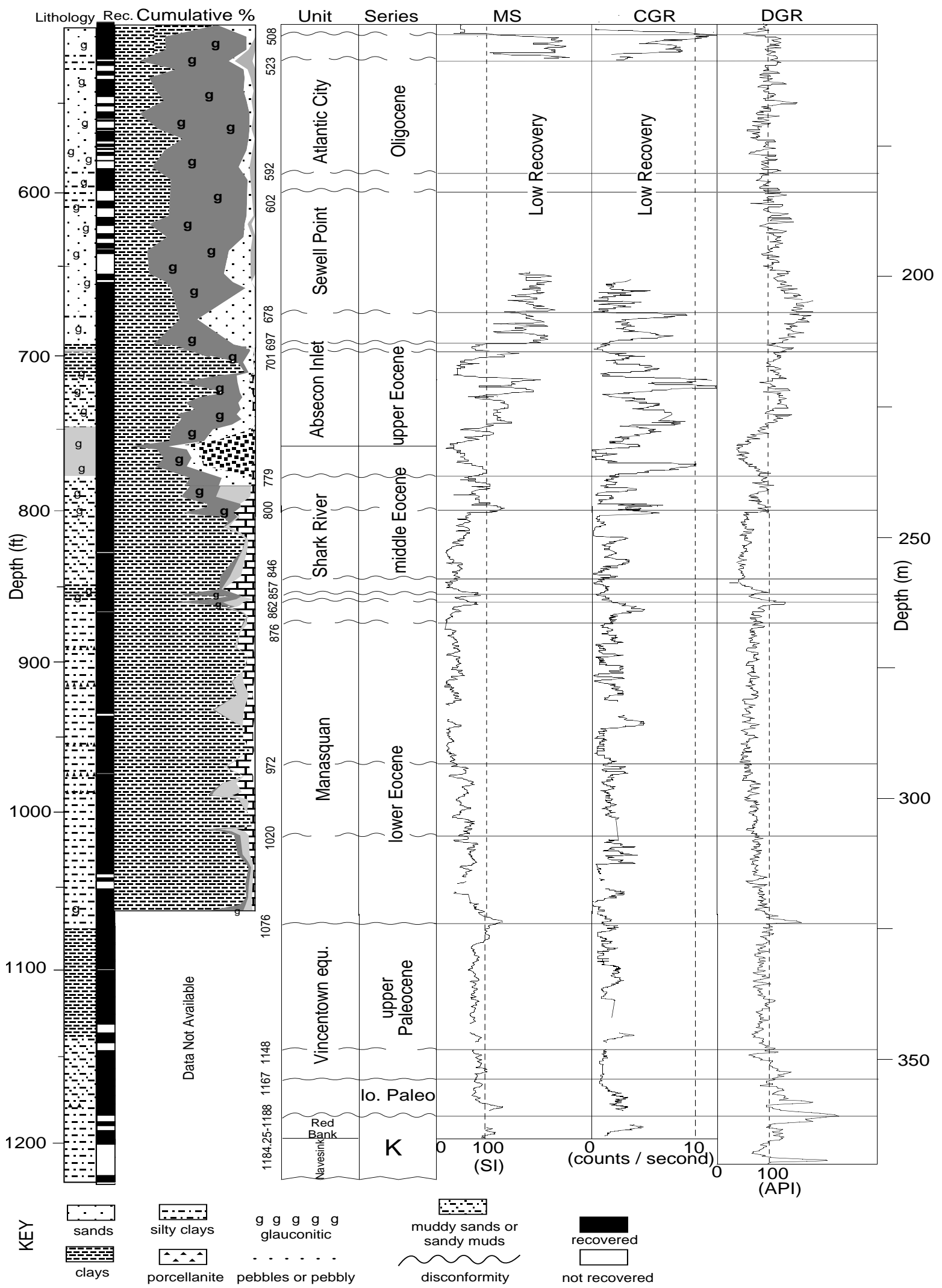

Figure 5. Paleocene, Eocene, and Oligocene lithostratigraphy, recovery, sequences, ages, MS, CGR, and DGR at Island Beach (500-1223 ft). Lithology modified after Miller et al. (1994b). Open intervals are sections with no recovery $\left(\mathrm{SI} \times 10^{-6}\right)$. 


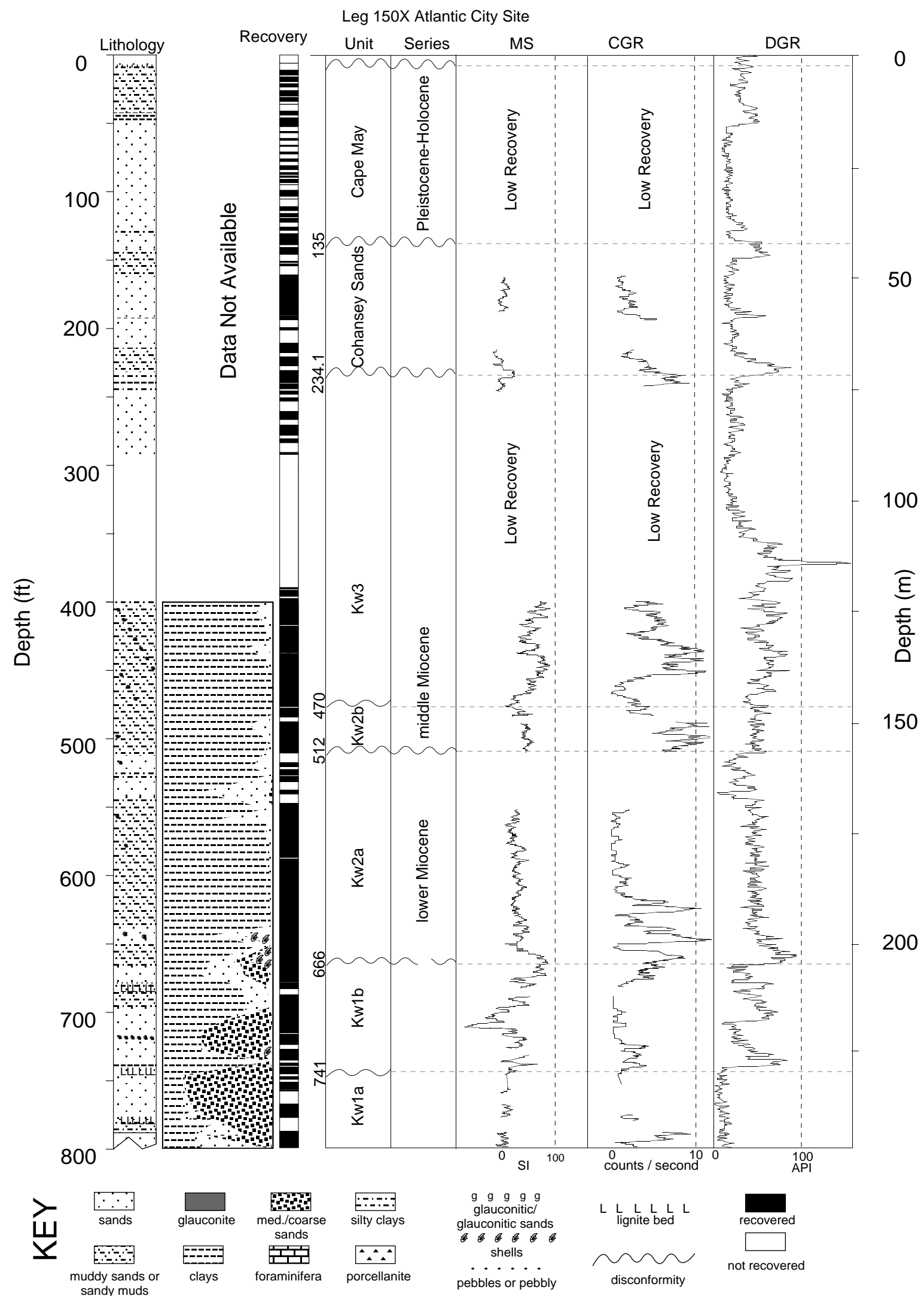

Figure 6. Miocene to Holocene lithostratigraphy, recovery, sequences, ages, MS, CGR, and DGR. at Atlantic City (0-800 ft). Lithology modified after Miller et al., 1994a $\left(\mathrm{SI} \times 10^{-6}\right)$. Open intervals are sections with no recovery. 


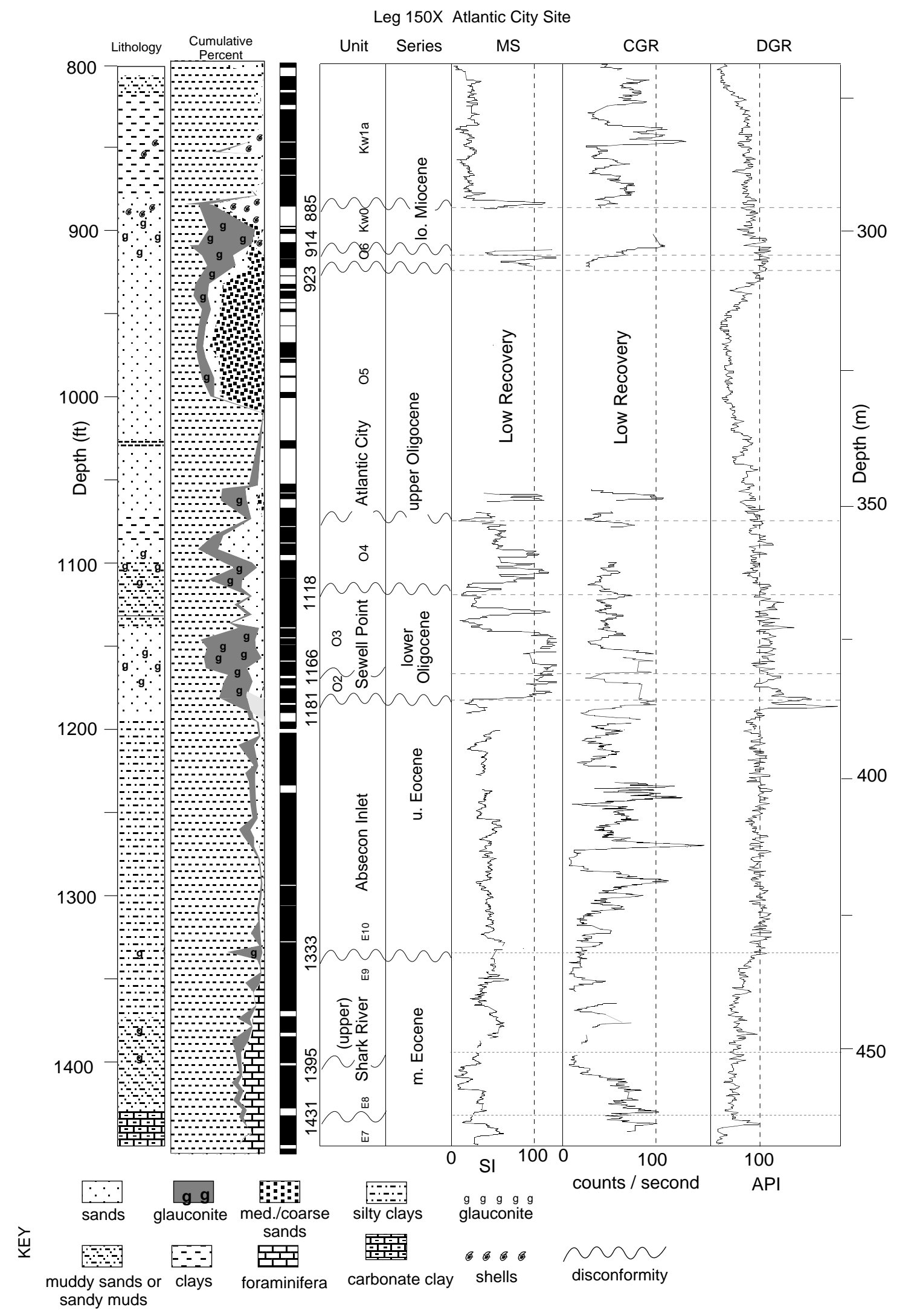

Figure 7. Eocene, Oligocene, and Miocene lithostratigraphy, recovery, sequences, ages, MS, CGR, and DGR at Atlantic City (800-1452 ft). Lithology modified after Miller et al., 1994a $\left(\mathrm{SI} \times 10^{-6}\right)$. Open intervals are section with no recovery. 


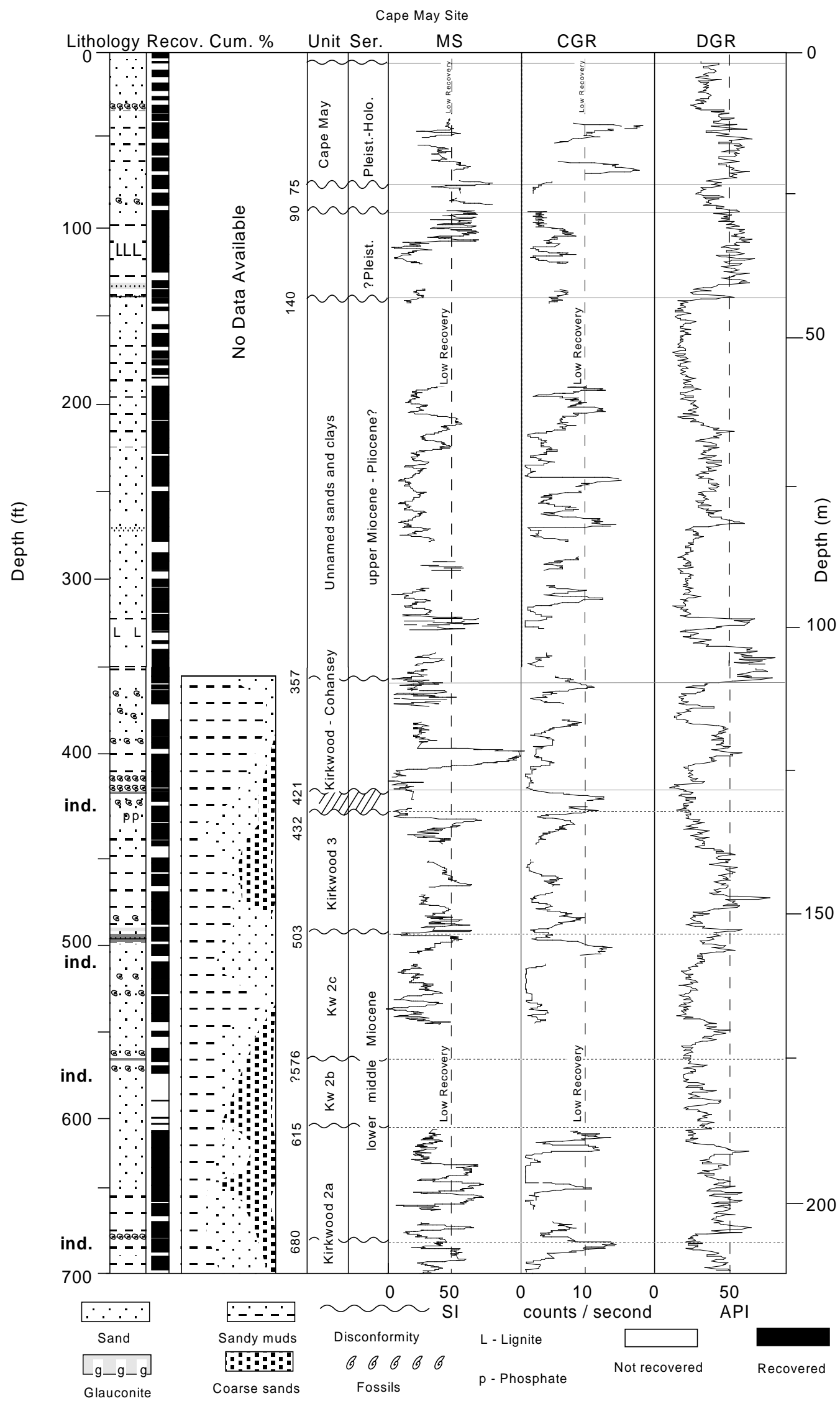

Figure 8. Miocene to Holocene lithology, recovery, sequences, ages, MS, CGR, and DGR at Cape May (0-700 ft). Open intervals are sections with no recovery. Lithology modified after Miller, et al. (1996; SI $\left.\times 10^{-6}\right)$. 


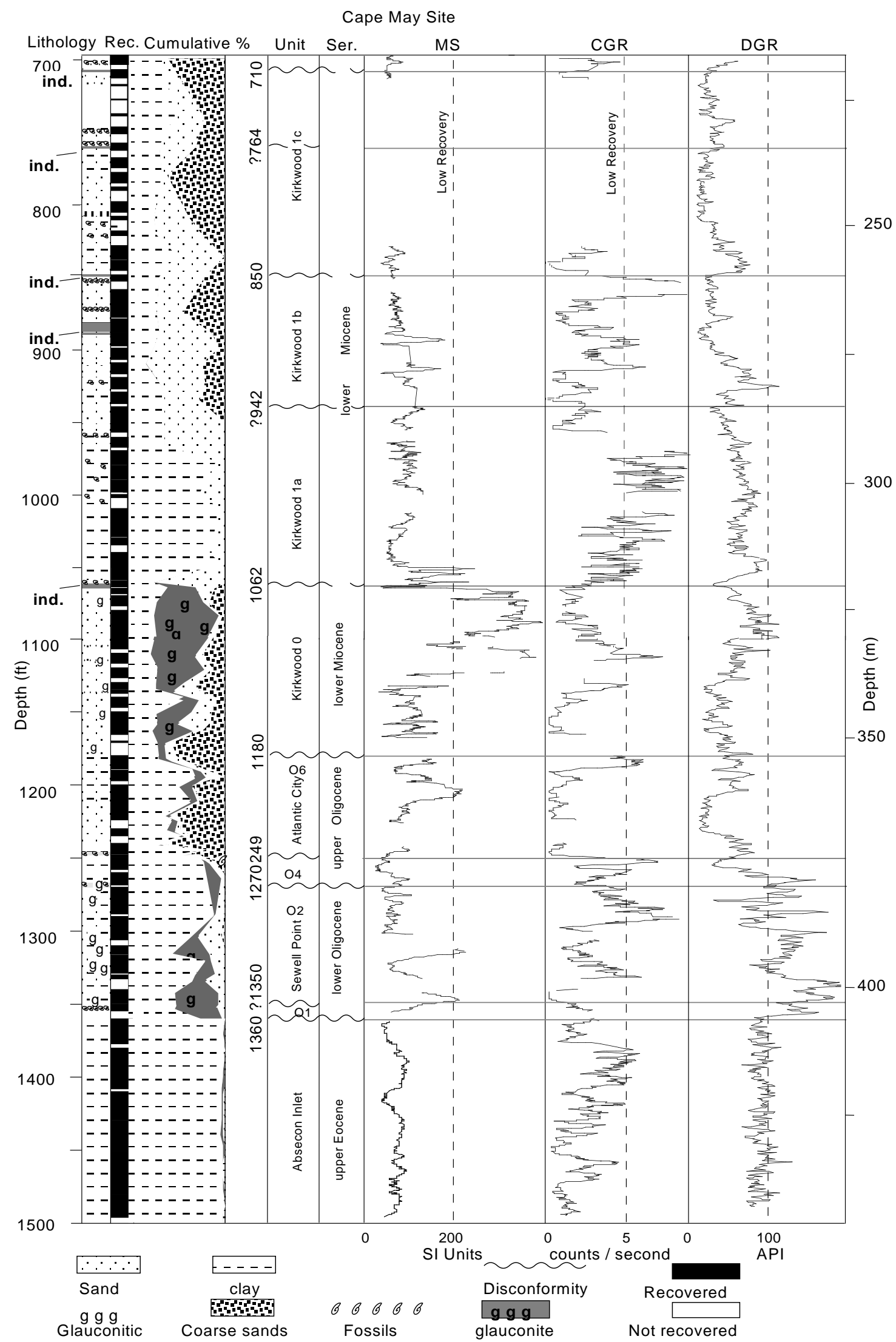

Figure 9. Eocene, Oligocene, and Miocene lithology, recovery, sequences, ages, MS, CGR, and DGR at Cape May (700-1500 ft). Open intervals are sections with no recovery. Lithology modified after Miller, et al. $\left(1996\right.$; SI $\left.\times 10^{-6}\right)$. 